\title{
Construction of Vocational Interests Scale for Young Chinese
}

\author{
Jian $\mathrm{Li}^{1}{ }^{1,2,3} \mathrm{Chu} \mathrm{Xu},{ }^{1}$ Changjin $\mathrm{Li}^{1}{ }^{1}$ and Houcan Zhang ${ }^{1}$ \\ ${ }^{1}$ Faculty of Psychology, Beijing Normal University, Beijing, China \\ 2 Beijing Key Laboratory of Applied Experimental Psychology, Beijing, China \\ ${ }^{3}$ Beijing Advanced Innovation Center for Future Education, Beijing, China
}

\begin{abstract}
Holland's RIASEC vocational interest typology may not be fully applicable to Chinese populations, and adapting models from Western cultures directly may fail to address important constructs specifically tied to the Chinese cultural background. This study made an exploration into Chinese college students' vocational interests and built a new self-report vocational interests scale based on Chinese university student samples. In study 1, researchers constructed a self-report vocational interests inventory developed from an item pool based on open-ended questionnaires and previous scales. Nine dimensions were identified through exploratory factor analysis: Artistic, Biotic, Conventional, Expressive, Investigative, Operational, Social, Enterprising, and Adventurous. In study 2, confirmatory factor analysis was employed to test its construct validity, and the indexes indicated good fit. Empirical evidence proved adequate homogeneity reliability and test-retest reliability, as well as sufficient concurrent validity with the Self-Directed Search. Thus, evidence lent support for the psychometrical properties of this scale. This exploratory research may expand our view of cross-cultural, vocational interest theories.
\end{abstract}

Keywords: vocational interests scale, Chinese, factor analysis

Vocational interests as a determinant of career choice (Humphreys \& Yao, 2002) have been gaining attention as theories and measurements of this concept have been widely applied in vocational counselling (Campbell \& Borgen, 1999; Rayman \& Atanasoff, 1999) and its potential value in personnel selection was revealed (Van Iddekinge, Putka, \& Campbell, 2011). In China, since the enrolment expansion of higher education exacerbated competition in the Chinese labour market and made the choice of vocation crucial to an individual's life, the government, students, educators, and researchers are paying even more attention to vocational interests and its practical application. Therefore, accurate measurement of Chinese vocational interests has become increasingly significant.

Holland's RIASEC typology and hexagonal structure are the most popular theoretic framework and organisational structure in vocational interest inventories (Rottinghaus \& Dik, 2013). But studies have shown that the hexagonal structure is not easily applicable to Chinese populations (e.g., Long \& Tracey, 2006; Tang, 2009). More specifically, there is not adequate and coherent evidence indicating the applicability of the RIASEC typology for Chinese populations (e.g., Tang, 2001; Y. Zhang, Kube, Wang, \& Tracey, 2013). However, most vocational in- terest measurement instruments used in China are still directly adapted from Western countries, based on Holland's model. This procedure may cause a major problem of failing to address important culture-specific types or dimensions that are indigenous to the Chinese cultural background. Besides, vocational interests may also vary in the fast-changing working patterns and lifestyles of this rapidly modernising society.

Thus, to provide a valid assessment instrument for Chinese vocational interests and to explore its general content and construct for the future career choices of young Chinese, this study aimed to establish an inventory based on indigenous Chinese samples and items.

\section{Definition and Theoretic Background of Vocational Interests}

Vocational interests, a key component of a person's work personality, has long been a central focus of career intervention and vocational psychology (Larson, Bonitz, \& Pesch, 2013). It refers to interests in choice of vocation and is defined as a relatively stable individual preference for certain types of work activities and environments (Dik \& Hansen, 2008; Harmon, Hansen, Borgen, \& Hammer, 1994; Low, Yoon, Roberts, \& Rounds, 2005).

This research was supported by The Twelfth Five Year Guideline Project of Beijing Educations Scientific Research (CBA15048).

Address for correspondence: Jian Li, Faculty of Psychology, Beijing Normal University, No. 19, XinJieKouWai St., HaiDian District, Beijing. 100875, China.Email: jianli@bnu.edu.cn 
Vocational interests have proven to be important for achievement in working environments and educational settings, given their relationship with outcome variables like job performance and job satisfaction (Spokane, 1985; Hansen, 2005). Also, the measurement of vocational interests has important significance in practice, as Carless (1999) noted: vocational interests assessment can enhance client self-understanding, promote self-exploration, and assist realistic decision making by providing feedback, new perspectives, and information. Vocational interest inventories are among the most commonly used measures in career counselling practice (Hansen, 2005).

The most influential and best-known theory of vocational interests is Holland's hexagonal model (Holland, 1973, 1997; Holland \& Gottfredson, 1992). Holland (1997) categorised preferences for activities in the workplace into six general types: Realistic (R), Investigative (I), Artistic (A), Social (S), Enterprising (E), and Conventional (C) (RIASEC). These types were arranged in a hexagon in the order of R-I-A-S-E-C. Briefly, Realistic interests reflect the appreciation of things, being outdoors, and working with one's hands. Investigative interests are typified by interests in science, thinking, and problem solving. Artistic interests define those who are creative and who rely on feelings and appreciate aesthetics. Social interests refer to the disposition to help and teach others. Enterprising interests are characterised by business and entrepreneurial pursuits, as well as motivating, persuading, and leading others. Conventional interests capture a preference for conscientious, organised, and detail-oriented practices (Holland, 1997). In light of Holland's (1997) theory, vocational interests are an expression of the congruence between one's personality and work, and the fit between the person and the work environment will have profound effects on vocational satisfaction, stability, and achievement.

Anchored conceptually in Holland's theory, some vocational interest measurements have been developed, such as the Vocational Preference Inventory (VPI) and the Self-Directed Search (SDS) (Holland, 1985a, 1985b, 1994; Holland \& Messer, 2013). Several other popular interest inventories, such as the Campbell Interest and Skills Survey (CISS; Campbell, Hyne, \& Nilsen, 1992) and the Strong Interest Inventory (SII; Donnay, Morris, Shaubhut, \& Thompson, 2005; Harmon et al., 1994) have adopted Holland's RIASEC typology to some extent since the 1970s to organise results (Savickas, Taber, \& Spokane, 2002).

\section{Challenges for the Holland's RIASEC Typology}

Although Holland's model of vocational interests is broad and inclusive, and has served as the basis of conceptions of research and assessment for over 50 years (Nauta, 2010), there have been arguments concerning this theory for a long time. The first issue is the validity of the six types themselves. Are the six RIASEC types arbitrary? Tracey and Rounds (1995) examined whether interests' item responses could be clustered into six natural groups, but found that items were uniformly arranged in a circle, and both an eight-scales model and the six-RIASEC-scales model fit the data equally well. Deng, Armstrong, and Rounds (2007) found that the RIASEC types were not sufficient to represent the full range of occupations in the United States. These results indicate that there might not be a strong enough empirical basis for the existence and representativeness of the six RIASEC types.

Realising that the RIASEC types may not adequately represent the complexity of the vocational interest space, some researchers noted the issue of more specificity in interest assessment (Borgen \& Lindley, 2003; Day \& Rounds, 1997), especially given the incremental validity of using more specific basic interests in predicting job satisfaction (Rottinghaus, Hees, \& Conrath, 2009). More specific interest types are conceptions analogous to facets in personality theory, with more specific facets underlying a more global scale such as the RIASEC types. From such a perspective, vocational interests can be viewed from a variety of levels of specificity depending on the purpose of assessment (Tracey \& Sodano, 2013). Since the six types initially proposed by Holland might not be the perfect solution, we should reconsider what should be the content of vocational interests. And this is an issue that should be discussed with consideration of cultural background and international differences.

\section{Problems of Applying the Holland's Model in Chinese Populations}

Since the validity of the six RIASEC types themselves has been challenged by scholars from the United States, we have reason to doubt whether the six RIASEC types originally proposed by Holland can fully represent Chinese vocational interests. A similar example could be addressed from the field of personality. Cheung et al. (2001) investigated the universality and sufficiency of the Big Five Personality Traits in China with the Revised NEO Personality Inventory (NEO-PI-R) and an indigenous measure - the Chinese Personality Assessment Inventory (CPAI; Cheung et al., 1996). Instead of the well-known, five-factor model, they found a six-factor model with an additional and unique Chinese factor named Interpersonal Relatedness in their Chinese samples. This cross-cultural difference may be suggestive of a similar condition underlying the issue of Chinese vocational interests.

Unfortunately, there has been a lack of examination of interest content and structure across cultures (Tracey \& Sodano, 2013). Tang (2001) examined the structures of 25 basic interest scales in the Strong Interest Inventory using Chinese samples, but did not completely duplicate the RIASEC themes, with a merger of basic interest scales between Social and Artistic, and a missing Conventional type. On the other hand, the application of the Personal Globe Inventory, one instrument incorporating both a six-RIASEC-type model and an eight-extendedtype model in China showed comparable fit between sixRIASEC types and eight types (Long, Adams, \& Tracey, 
2005; Y. Zhang et al., 2013). Due to the differences in measurement instruments and inconclusive results, definitive conclusions cannot be drawn from these studies. Moreover, when Holland's hexagonal structure is applied in China, researchers are confronted with problems. Farth, Leong, and Law (1998) found a lack of fit of the RIASEC model in Hong Kong populations. Yang, Stokes, and Hui (2005) demonstrated the inapplicability of Holland's RIASEC hexagon in both Mainland China and Hong Kong using the SDS. And in a structural meta-analysis for Chinese participants, Holland's model showed unacceptable fit (Long \& Tracey, 2006). Tang (2009) revealed that the interrelationships among the six RIASEC types for Chinese students are not exactly the same pattern as predicted by Holland.

Also, there is a lack of qualified studies focusing on Chinese indigenous vocational interests. The only reference is from H. Zhang, Feng, and Yuan (2004). They developed an interest scale for college entrance and for career guidance, targeted at Chinese high school students. With factor analysis, they produced seven vocational interest dimensions, including a new type named 'Natural', which refers to those who have a curiosity and passion for natural things such as animals and plants (H. Zhang et al., 2004). When looking into the content of vocational interests, the emergence of a main dimension, 'Natural', seems to conflict with the original RIASEC themes, where the preferences for nature is only a facet or subscale underlying the general type 'Realistic'. This study reminds us again of the power of cultural differences and that the six RIASEC themes might not be the perfect solution for Chinese.

After all, the primary objective of vocational interest assessment is to help individuals learn about their interests and match these with apposite occupations. Therefore, renewed attention to this issue is needed.

\section{A Call for Chinese Indigenous Measures}

While many instruments measuring vocational interests, such as the SII, the CISS, and the SDS, have been built and are utilised in Western cultures, especially in the United States, Chinese studies focusing on domestic scale development are rare. In most cases, Chinese researchers directly translate or adapt measurement instruments from foreign countries, which is a typical etic approach. However, this procedure should be treated with caution because: (a) it fails to address important culture-specific constructs that are indigenous to a particular culture; (b) responses to the items may not work similarly and may be influenced by culture; and (c) work activities and occupational titles could vary a great deal across cultures (Church, 1987; Liu \& Rounds, 2003; Tracey \& Sodano, 2013; Yung et al., 2000). Therefore, instead of adapting and validating existing vocational interest inventories from Western cultures, we could consider the emic approach, focusing on identifying indigenous constructs to further explore Chinese vocational interests (see Ægisdóttir, Gerstein, Le- ung, Kwan, \& Lonner, 2009). An illuminating example is from Iceland, where researchers have developed a set of Icelandic indigenous basic interest scales, including eight general vocational interest clusters, after they found that Holland's RIASEC model did not perfectly correspond to the sample data (Einarsdóttir, Rounds, \& Su, 2010; Einarsdóttir, Eyjólfsdóttir, \& Rounds, 2013).

On the other hand, vocational interests depicting work preferences closely related to occupations will be shaped by the actual jobs and work environment of a society. China's accelerated development in this century has brought emerging occupations, changing work patterns, and new lifestyles. For instance, the number of undergraduate majors at universities in China was 506 in 2012 (Ministry of Education of the People's Republic of China, 2012). Many new occupations, such as web editor, landscape architect and flavourist, have emerged. In the meantime, people's work tasks and work environment have been constantly updated, resulting in a transformation of behavioural preferences for work. For example, with traditional manual labour in manufacturing being replaced by machines, there will be fewer simple mechanical operation jobs, resulting in a shift in people's pragmatic orientation towards that sort of work. And with the booming development of information technology, there will be more technical work in programming and data analysis. Thus, operational definitions of vocational interests may change over time just as the environment of work changes. Specific measurement items may become outdated. In this case, the construction of new vocational interest assessment instruments is indeed necessary.

\section{The Present Study}

Holland's vocational interest typology generated from Western cultures may not be perfectly applicable to Chinese populations. Directly employing instruments from Western countries will probably omit key constructs or dimensions specifically tied to the Chinese cultural background (Liu \& Rounds, 2003; Yung et al., 2000). With a fast-changing society, the definitions of original vocational interest types may alter, and items may need to be reconstructed. These problems call for a new vocational interest inventory built on indigenous Chinese samples.

Based on the above, the first goal of the present study was to develop a vocational interest scale based on indigenous Chinese samples to provide a practical measurement tool for researchers and educators. The second goal was to explore the latent structure of vocational interests in China, enhancing the theoretical framework for crosscultural studies. In the present study, the method of factor analysis was employed instead of commonly used analysis like multidimensional scaling that is often tied to the RIASEC typology. The reason we chose factor analysis is that the Holland's typology tends to classify people into different groups, but there is the possibility that individuals can have different magnitudes of disposition on different 
types; for example, high scores on opposing types. We assumed that vocational interests or career preferences that resemble personality traits can be measured in independent terms of factors.

\section{STUDY 1}

In study 1, we mainly aimed to formulate a new scale of Chinese vocational interests and explore its basic structure.

\section{Method}

\section{Item Generation}

In order to build a comprehensive item pool of contemporary Chinese vocational interests, the items forming the scale came from two different sources: one part was generated from descriptions produced by a sample of Chinese students and the other part consisted of items from existing vocational interest inventories.

Considering the main purpose of the Chinese vocational interest scale is to help young Chinese, especially those at college/university levels at the starting point of a career, to find out their job preferences, the source of item pool was targeted at typical college students. First, we administered a survey to a sample of 327 undergraduates. The participants were junior students from three educational psychology classes. Because educational psychology is a public required course open for all students who want to obtain a National Teacher Certificate, students were distributed throughout various departments with different majors. The survey asked the participants to imagine a perfect situation where they could live a life as they wanted, and to choose a dream job. Then participants were required to list at least three activities they thought they would most like to engage in under this imaginary working situation. From this procedure, we obtained a total of 291 unique brief descriptions of activities. An example of a student's response was 'edit video clips'.

Second, the responses were coded into items and the frequency of each item was counted. Then items under the same kind of activity with minor differences were merged. For instance, 'write a poem' and 'write a piece of prose' were combined into 'create literary works'. Third, items were sorted in descending order depending on the frequency. Only the items with a frequency no lower than 5 were retained, and 70 items remained.

Fourth, we used 66 items from the 'Activities' subtest of the SDS (Holland, 1994) as the other part of item resource, considering its popularity. The total 136 items were examined carefully by two psychometric professionals and seven psychology undergraduates. Repeated items and outdated items were deleted, and ambiguous expressions were modified.

Finally, we formed a new item inventory with 96 items. Further, four identical items were added to the end of the scale to check whether the participants rated the questionnaire seriously.
With regard to response format, we chose the 1-6 Likert-type ( 1 = strongly dislike; 6 = strongly like $)$ via asking participants the degree to which they would enjoy the activities described by the items. When assessing vocational interests, the intention was to understand respondents' magnitude of preferences, instead of having them make choices between items (Schermer, 2012). Also, the even multipoint Likert scale is better suited for multivariate statistical methods (such as factor analysis) rather than forced-choice measures (or ipsative measures) (Baron, 1996) as it reduces the tendency for respondents to select a neutral attitude (e.g., scale midpoint). Therefore, individual items were rated using a 6-point Likert scale with no midpoint.

\section{Participants}

The original Chinese Vocational Interests Scale of 100 items was administered to 1,110 participants. Using the four repeated items, we were able to confirm whether participants had completed these items faithfully. After excluding those participants with inconsistent responses on repeated items (the discrepancy between any two identical items cannot be greater than 2), 989 participants $(89.10 \%)$ were included in the analysis.

The final sample consisted of 989 college students from six different universities across northern and southern China. The participants' majors covered a wide range of professional fields, such as mathematics, clinical medicine, public administration, international trade, Chinese literature, and art and design.

Of the participants, 441 students were female (44.6\%), 460 were male $(46.5 \%)$, and 88 students did not report their gender $(8.9 \%)$; 629 were freshmen $(63.6 \%), 175$ were sophomores $(17.7 \%), 86$ were junior students $(8.7 \%), 1$ was senior student $(0.1 \%)$, and the remaining 98 students $(9.9 \%)$ did not report their grade.

\section{Statistical Analysis}

The responses to the 96 original items in the Chinese Vocational Interests Scale were submitted to an exploratory factor analysis (EFA) in Mplus 7.11, applying the recommended GEOMIN oblique rotation (Muthén \& Muthén, 1998-2012). In terms of normality, the absolute values of skewness for all 96 variables were under 1.0, and 93 variables had an absolute value of kurtosis smaller than 1.0 (the other 3 variables had an absolute value of kurtosis under 1.5). Considering the normality and the lack of a midpoint in the data (i.e., 6-point scale used), the Weighted Least Square Parameter Estimates with standard errors and mean- and variance-adjusted (WLSMV) chi-square test statistic was used in order to get more veracious estimation (Finney \& DiStefano, 2013; Muthén \& Muthén, 1998-2012). The rate of missing data was no more than $0.3 \%$, and the default mode of using all available data was employed (Muthén \& Muthén, 1998-2012). Model fit indices including chi-square, root mean square 


\begin{tabular}{|c|c|c|c|c|c|c|}
\hline Model & $x^{2}$ & $d f$ & RMSEA [90\% Cl] & SRMR & $\mathrm{CFI}$ & TLI \\
\hline 3-factor & $26,967.927^{* *}$ & 4,275 & $\begin{array}{l}0.073 \\
{[0.072,0.074]}\end{array}$ & 0.084 & 0.700 & 0.680 \\
\hline 4-factor & $21,790.859^{* *}$ & 4,182 & $\begin{array}{l}0.065 \\
{[0.064,0.066]}\end{array}$ & 0.070 & 0.767 & 0.746 \\
\hline 5-factor & $18,575.185^{* *}$ & 4,090 & $\begin{array}{l}0.060 \\
{[0.059,0.061]}\end{array}$ & 0.061 & 0.808 & 0.786 \\
\hline 6-factor & $15,549.200^{* *}$ & 3,999 & $\begin{array}{l}0.054 \\
{[0.053,0.055]}\end{array}$ & 0.051 & 0.847 & 0.826 \\
\hline 7-factor & $13,750.034^{* *}$ & 3,909 & $\begin{array}{l}0.050 \\
{[0.050,0.051]}\end{array}$ & 0.044 & 0.870 & 0.848 \\
\hline 8-factor & $11,588.116^{* *}$ & 3,820 & $\begin{array}{l}0.045 \\
{[0.044,0.046]}\end{array}$ & 0.037 & 0.897 & 0.877 \\
\hline 9-factor & $9,961.817^{* *}$ & 3,732 & $\begin{array}{l}0.041 \\
{[0.040,0.042]}\end{array}$ & 0.032 & 0.918 & 0.899 \\
\hline 10-factor & $8,866.917^{* *}$ & 3,645 & $\begin{array}{l}0.038 \\
{[0.037,0.039]}\end{array}$ & 0.029 & 0.931 & 0.914 \\
\hline 11-factor & $8,288.893^{* *}$ & 3,559 & $\begin{array}{l}0.037 \\
{[0.036,0.038]}\end{array}$ & 0.027 & 0.937 & 0.920 \\
\hline
\end{tabular}

Note: RMSEA = root mean square error of approximation; $\mathrm{Cl}=$ confidence interval; SRMR = standardised root mean square residual; $\mathrm{CFI}=$ comparative fit index; $\mathrm{TLI}=$ Tucker-Lewis index .

** $p<.01$.

error of approximation (RMSEA), comparative fit index (CFI), Tucker-Lewis index (TLI) and standardised root mean square residual (SRMR) were adopted to evaluate model fitness.

\section{Results}

The data produced 17 eigenvalues larger than 1.0 (between 20.467 and 1.029). Among these, 9 eigenvalues were larger than 2.0 and 6 eigenvalues were larger than 3.0. An inspection of the scree plot (Cattell, 1966) suggested that 9- to 11-factor solutions should be considered. Based on these results, as well as the four-dimension structure from previous studies (Tracey \& Rounds, 1996a, 1996b), we examined nine models, with 3 to 11 factors being extracted to determine the number of factors in the data (Fabrigar, Wegener, MacCallum, \& Strahan, 1999).

As presented in Table 1, fit indices supported the 9factor model as most appropriate for the current data. The 9-factor model exhibited acceptable fitness ( $\mathrm{Hu} \&$ Bentler, 1999; McDonald \& Ho, 2002), which was substantially better than the 8 -factor model $(\Delta \mathrm{CFI}=0.021)$, and comparable to the 10 -factor model $(\triangle \mathrm{CFI}=-0.013$; Cheung \& Rensvold, 2002; Meade, Johnson, \& Braddy, 2008). Moreover, when we investigated the rotated factor loadings of each item in the 10-factor model, only five items loading on the tenth factor exceeded 0.30 , none of the five values was beyond 0.45 , and three of the items had cross loadings (loaded at or above 0.3 ) on more than one factor. The same pattern appeared for the 11-factor model, with only five items loading between 0.30 and 0.50 on the 10th and 11th factors respectively, indicating that a latent structure of more than 9 factors was not sufficiently succinct or interpretable. Therefore, the 9 -factor solution was employed in view of the goodness of fit and the interpretability of solutions (Fabrigar et al., 1999).

Items with all factor loadings under 0.30 were viewed as a poor fit to the factor structure, and items with cross loadings were treated as not interpretable. These items were deleted from further analyses. Also, considering the length of the scale, the reduction of items was necessary for the purpose of avoiding some measurement issues like boredom or fatigue with long scales. We further selected the items carefully following three rules: (a) the loading of the item on the intended factor should be relatively high; (b) the item-subscale total correlation of the item should be relatively high; (c) the content of the items under the same factor should be representative and heterogeneous as much as possible. Finally, 54 items from the Chinese original scale were retained with six items under each factor. The goodness of the model fit is shown in Table 2.

We initially defined nine factors as Artistic (A), Biotic (B), Conventional (C), Expressive (X), Investigative (I), Operational (O), Social (S), Enterprising (E), and Adventurous $(\mathrm{V})$. Table 3 shows the contents and loadings of the 54 items on each of the nine factors (please find the English and Chinese wordings of the items in the Appendix). Table 4 depicts the descriptive statistics, correlations, and internal consistency reliabilities of the resulting subscales.

\section{Discussion}

In study 1 we developed a new interests scale, the Chinese Vocational Interests Scale, with 54 items. The results of the EFA showed that the vocational interests of the Chinese sample yielded nine factors. These factors are detailed below. The first factor, Artistic (A), measures whether individuals like activities where imagination and 


\begin{tabular}{|c|c|c|c|c|c|c|}
\hline Model & $x^{2}$ & $d f$ & RMSEA $[90 \% \mathrm{Cl}]$ & SRMR & CFI & TLI \\
\hline 9-factor with 54 items & $2,589.913^{* *}$ & 981 & $0.041[0.039,0.043]$ & 0.023 & 0.960 & 0.942 \\
\hline
\end{tabular}

creativity are needed, and whether they like to pursue artistic values and beauty. Examples of relevant occupations are writers, photographers, and graphic designers. The second factor, Biotic (B), measures whether individuals have a great interest in living things and the nature. People with a relatively higher level of Biotic like to raise and observe the growth of animals and plants. Examples of relevant occupations are agricultural researchers, horticulturists, and animal trainers. The third factor, Conventional $(\mathrm{C})$, measures whether individuals like highly rational, regular, and systematic activities. People of this kind prefer well-regulated environments. Examples of relevant occupations are actuaries, auditors, and secretaries. The fourth factor, Expressive (X), measures whether individuals like being in public, being the focus of attention, and influencing the public. Examples of relevant occupations are emcees, actors, and reporters. The fifth factor, Investigative (I), measures whether individuals are filled with curiosity, highly critical, and prefer to solve problems by observing, analysing, and reasoning. Examples of relevant occupations are scientific researchers, medical researchers, and communication engineers. The sixth factor, Operational $(\mathrm{O})$, measures whether individuals like activities requiring handcraft, operation of tools, and the use of materials in order to make objects. Examples of relevant occupations are surgeons, construction engineers, and machinists. The seventh factor, social (S), measures whether individuals like social interactions and helping others, as well as communicating with others. Examples of relevant occupations are social workers, middle school teachers, and football coaches. The eighth factor, Enterprising (E), measures whether individuals like to manage and control others' thoughts and behaviours. People with a relatively higher level of Enterprising are usually sensitive to economic benefits. They often want to take power and dominate social resources. Examples of relevant occupations are managers, government administrators, and chief executive officers (CEOs). The ninth factor, Adventurous $(\mathrm{V})$, measures whether individuals like highly challenging activities and taking risk. People of this kind are interested in sports and outdoor activities. Examples of relevant occupations are professional sports people, firemen, and lifesavers.

\section{STUDY 2}

The aim of study 2 was to replicate the 9-factor model from study 1 with CFA (Worthington \& Whittaker, 2006). In addition, we provided more construct validity evidence by testing the correlations between the Chinese Vocational Interests Scale and the SDS, based on Holland's vocational interests theory (Holland, 1994). We also provided reliability evidence with Cronbach's alpha and test-retest reliability.

\section{Method}

\section{Participants}

In this study, 1,118 participants completed the Chinese Vocational Interests Scale, Self-Directed Search and demographic information. After deleting cases with inconsistent responses on the repeated items (the discrepancy between any two identical items must not exceed 2), 970 participants $(86.76 \%)$ were included in the final analysis.

The sample consisted of 970 college students from the same six universities across China as in study 1. Participants' majors also presented diversity, such as Computer Science, Civil Engineering, Accountancy, Marketing, Nursing, and English. Among these participants, 432 students were female $(44.5 \%), 439$ students were male $(45.3 \%)$, and 99 students did not report their gender (10.2\%); 599 were freshmen (61.8\%), 162 were sophomores (16.7\%), 95 were junior students (9.8\%), and 114 students (11.8\%) did not report their grade.

Two classes of college students (86 students) were selected from the participants who had taken part in the previous investigation in order to retest the Chinese Vocational Interests Scale. Seventy-seven cases $(89.53 \%)$ were included in the final sample of the retest (nine cases were excluded due to inconsistent responses on the repeated items). Of these, 46 participants were female (59.7\%), 46 (59.7\%) were freshmen, 30 (39.0\%) were sophomores, and 1 was a junior student. The time interval of retest was 2 weeks.

\section{Measures}

The Chinese Vocational Interests Scale (VIS). The ninefactor Vocational Interests Scale with 58 items ( 54 original items and 4 repeated items) developed in study 1 was used.

Self-Directed Search (Form R - 4th Edition; SDS). The Activities subtest of the SDS (Holland, 1994) was also used to measure vocational interests and to supply evidence for concurrent validity. This measure contains 11 items for each dimension and 66 items in total. Participants have to choose between 'Like' and 'Dislike' for each item (Like $=1$; Dislike $=0)$. An example of the items is 'Operate motorised machines or equipment'. To ensure the accuracy 
Table 3

EFA Rotated Factor Loadings of the 54 Items of the Chinese Vocational Interests Scale $(n=989)$

\begin{tabular}{|c|c|c|c|c|c|c|c|c|c|}
\hline \multirow[b]{2}{*}{ Factors and items } & \multicolumn{9}{|c|}{ Loadings } \\
\hline & 1 & 2 & 3 & 4 & 5 & 6 & 7 & 8 & 9 \\
\hline \multicolumn{10}{|l|}{ Factor 1: Artistic } \\
\hline $\begin{array}{l}\text { 1. Design packaging of a new } \\
\text { product }\end{array}$ & .689 & -0.013 & -0.074 & 0.011 & 0.055 & 0.035 & -0.008 & 0.072 & -0.041 \\
\hline $\begin{array}{l}\text { 2. Design the logo of a company or } \\
\text { an organization }\end{array}$ & .608 & -0.001 & -0.065 & -0.057 & 0.080 & 0.065 & -0.033 & 0.179 & -0.009 \\
\hline 3. Create portraits or photographs & .430 & 0.033 & -0.014 & 0.118 & 0.090 & -0.023 & 0.045 & -0.063 & -0.038 \\
\hline $\begin{array}{l}\text { 4. Write lyrics or compose music of } \\
\text { any kind }\end{array}$ & .332 & 0.022 & 0.036 & 0.223 & 0.258 & -0.150 & -0.034 & -0.057 & 0.069 \\
\hline $\begin{array}{l}\text { 5. Design furniture, clothing, or } \\
\text { posters }\end{array}$ & .763 & -0.007 & 0.052 & 0.018 & -0.078 & 0.010 & 0.029 & 0.014 & 0.048 \\
\hline 6. Design stage scenery for a play & .622 & 0.028 & 0.133 & 0.105 & -0.015 & 0.013 & 0.076 & 0.008 & 0.021 \\
\hline \multicolumn{10}{|l|}{ Factor 2: Biotic } \\
\hline $\begin{array}{l}\text { 1. Watch documentary films or TV } \\
\text { programs about animals or other } \\
\text { creatures }\end{array}$ & 0.017 & 0.595 & 0.058 & -0.119 & 0.018 & -0.015 & 0.022 & -0.002 & 0.009 \\
\hline $\begin{array}{l}\text { 2. Observe or record the growth of } \\
\text { plants }\end{array}$ & -0.017 & 0.808 & 0.083 & 0.025 & 0.065 & 0.003 & -0.005 & -0.053 & -0.045 \\
\hline $\begin{array}{l}\text { 3. Collect or make biological } \\
\text { specimens }\end{array}$ & 0.007 & 0.803 & 0.051 & 0.038 & -0.042 & 0.046 & -0.011 & -0.029 & -0.027 \\
\hline 4. Track or observe wild animals & 0.003 & 0.828 & -0.073 & -0.016 & 0.050 & -0.013 & -0.043 & 0.023 & 0.051 \\
\hline $\begin{array}{l}\text { 5. Cultivate new varieties of animals } \\
\text { or plants }\end{array}$ & 0.085 & 0.686 & -0.015 & -0.012 & -0.060 & 0.044 & 0.053 & 0.037 & 0.010 \\
\hline $\begin{array}{l}\text { 6. Observe or record the habits of } \\
\text { small animals like ants }\end{array}$ & -0.026 & 0.764 & -0.003 & 0.002 & 0.033 & -0.020 & -0.016 & 0.029 & 0.078 \\
\hline \multicolumn{10}{|l|}{ Factor 3: Conventional } \\
\hline $\begin{array}{l}\text { 1. Regularly make neat or update an } \\
\text { address book }\end{array}$ & 0.041 & -0.005 & 0.670 & 0.032 & -0.053 & 0.086 & 0.043 & -0.009 & -0.050 \\
\hline $\begin{array}{l}\text { 2. Take inventory of supplies or } \\
\text { products }\end{array}$ & -0.002 & -0.010 & 0.712 & -0.026 & 0.047 & 0.036 & -0.053 & 0.083 & 0.029 \\
\hline $\begin{array}{l}\text { 3. Check paperwork or products for } \\
\text { errors or flaws }\end{array}$ & -0.046 & 0.062 & 0.694 & 0.009 & 0.152 & -0.104 & -0.007 & 0.014 & 0.059 \\
\hline 4. Keep detailed records of expenses & 0.022 & 0.058 & 0.572 & 0.004 & 0.062 & -0.065 & 0.012 & 0.021 & 0.044 \\
\hline 5. Handle daily affairs in office & -0.011 & 0.034 & 0.475 & 0.112 & -0.049 & 0.093 & 0.228 & 0.053 & -0.104 \\
\hline $\begin{array}{l}\text { 6. Classify or put different kinds of } \\
\text { items in order }\end{array}$ & 0.049 & -0.056 & 0.490 & -0.079 & 0.026 & 0.093 & 0.216 & 0.018 & -0.089 \\
\hline \multicolumn{10}{|l|}{ Factor 4: Expressive } \\
\hline $\begin{array}{l}\text { 1. Perform dance or traditional } \\
\text { Chinese opera for others }\end{array}$ & 0.165 & -0.019 & 0.066 & 0.613 & -0.022 & -0.079 & 0.004 & -0.112 & 0.149 \\
\hline 2. Become a public figure & -0.070 & -0.014 & -0.034 & 0.779 & 0.117 & 0.036 & -0.022 & 0.065 & 0.022 \\
\hline $\begin{array}{l}\text { 3. Be the emcee or compere of a } \\
\text { show or a TV program }\end{array}$ & 0.077 & -0.006 & 0.038 & 0.718 & -0.049 & -0.006 & 0.050 & 0.036 & 0.026 \\
\hline 4. Dress myself out of the ordinary & 0.042 & -0.016 & 0.019 & 0.704 & 0.035 & -0.022 & -0.161 & -0.022 & 0.011 \\
\hline $\begin{array}{l}\text { 5. Become the image endorsement } \\
\text { of a product or company }\end{array}$ & 0.052 & 0.048 & -0.046 & 0.769 & -0.114 & 0.016 & 0.040 & 0.081 & -0.024 \\
\hline $\begin{array}{l}\text { 6. Attend an event as an award } \\
\text { presenter }\end{array}$ & -0.069 & 0.006 & -0.006 & 0.638 & 0.047 & 0.025 & 0.200 & 0.045 & -0.109 \\
\hline \multicolumn{10}{|l|}{ Factor 5: Investigative } \\
\hline $\begin{array}{l}\text { 1. Explore the causes of a } \\
\text { phenomenon or an incident }\end{array}$ & -0.001 & 0.169 & -0.051 & 0.075 & 0.519 & 0.081 & 0.051 & 0.027 & -0.029 \\
\hline $\begin{array}{l}\text { 2. Verify a scientific theory with } \\
\text { practice }\end{array}$ & -0.020 & 0.042 & -0.047 & 0.051 & 0.574 & 0.166 & 0.144 & 0.049 & -0.038 \\
\hline $\begin{array}{l}\text { 3. Think about the principles of how } \\
\text { things develop or change }\end{array}$ & -0.053 & 0.037 & 0.029 & -0.012 & 0.738 & 0.104 & 0.005 & -0.026 & 0.004 \\
\hline $\begin{array}{l}\text { 4. Learn about different scientific } \\
\text { theories via books or lectures }\end{array}$ & 0.039 & 0.040 & 0.079 & -0.036 & 0.686 & -0.027 & 0.051 & -0.005 & 0.091 \\
\hline $\begin{array}{l}\text { 5. Study a certain theory in depth } \\
\text { through a series of references or } \\
\text { data. }\end{array}$ & 0.078 & -0.051 & 0.077 & -0.015 & 0.818 & 0.007 & -0.013 & 0.021 & 0.019 \\
\hline $\begin{array}{l}\text { 6. Apply science to practical } \\
\text { problems }\end{array}$ & 0.077 & 0.021 & 0.016 & -0.015 & 0.505 & 0.256 & 0.059 & 0.057 & -0.048 \\
\hline
\end{tabular}


Table 3

Continued

\begin{tabular}{|c|c|c|c|c|c|c|c|c|c|}
\hline \multirow[b]{2}{*}{ Factors and items } & \multicolumn{9}{|c|}{ Loadings } \\
\hline & 1 & 2 & 3 & 4 & 5 & 6 & 7 & 8 & 9 \\
\hline \multicolumn{10}{|l|}{ Factor 6: Operational } \\
\hline 1. Maintain a computer network & -0.017 & -0.069 & 0.066 & -0.018 & 0.039 & 0.655 & 0.001 & 0.019 & 0.002 \\
\hline 2. Shape metal or plastic with tools & 0.017 & 0.074 & -0.001 & -0.042 & -0.008 & 0.731 & -0.029 & -0.049 & 0.048 \\
\hline $\begin{array}{l}\text { 3. Repair garments or electronic } \\
\text { equipment }\end{array}$ & 0.139 & 0.074 & 0.051 & -0.006 & -0.067 & 0.690 & 0.092 & -0.073 & -0.032 \\
\hline 4. Operate machines or devices & -0.033 & 0.038 & 0.016 & -0.013 & 0.034 & 0.753 & 0.044 & 0.022 & 0.070 \\
\hline $\begin{array}{l}\text { 5. Assemble precision instruments } \\
\text { or meters }\end{array}$ & 0.004 & 0.000 & 0.034 & 0.053 & 0.091 & 0.718 & -0.081 & -0.002 & 0.110 \\
\hline $\begin{array}{l}\text { 6. Refit computers or other } \\
\text { equipment in order to improve } \\
\text { their efficiency }\end{array}$ & 0.013 & -0.046 & -0.091 & 0.013 & 0.198 & 0.641 & -0.126 & 0.094 & 0.074 \\
\hline \multicolumn{10}{|l|}{ Factor 7: Social } \\
\hline $\begin{array}{l}\text { 1. Talk with people to help make } \\
\text { them happy }\end{array}$ & -0.003 & 0.020 & -0.009 & 0.053 & 0.051 & 0.014 & 0.719 & 0.089 & -0.048 \\
\hline $\begin{array}{l}\text { 2. Help tutoring neighborhood } \\
\text { children }\end{array}$ & -0.008 & -0.027 & 0.056 & 0.074 & 0.017 & 0.093 & 0.670 & -0.067 & 0.040 \\
\hline $\begin{array}{l}\text { 3. Care about poor, sick or lonely } \\
\text { people }\end{array}$ & 0.015 & -0.030 & 0.008 & -0.013 & 0.014 & -0.063 & 0.842 & -0.033 & 0.130 \\
\hline 4. Work for a charity & 0.047 & 0.023 & -0.017 & 0.003 & 0.009 & -0.077 & 0.745 & 0.024 & 0.130 \\
\hline $\begin{array}{l}\text { 5. Keep neighboring elderly people } \\
\text { company }\end{array}$ & 0.072 & 0.054 & 0.032 & -0.037 & -0.029 & -0.048 & 0.693 & 0.027 & 0.124 \\
\hline $\begin{array}{l}\text { 6. Encourage colleagues when they } \\
\text { are feeling down or faced with } \\
\text { difficulties }\end{array}$ & -0.020 & -0.047 & 0.012 & 0.003 & 0.062 & 0.040 & 0.732 & 0.143 & -0.032 \\
\hline \multicolumn{10}{|l|}{ Factor 8: Enterprising } \\
\hline $\begin{array}{l}\text { 1. Plan for the developmental } \\
\text { orientation of a team or company }\end{array}$ & 0.102 & -0.023 & 0.004 & -0.018 & 0.081 & -0.021 & 0.007 & 0.812 & -0.022 \\
\hline $\begin{array}{l}\text { 2. Make investment analysis for a } \\
\text { company }\end{array}$ & 0.017 & -0.029 & 0.099 & -0.023 & 0.129 & -0.020 & -0.060 & 0.758 & 0.026 \\
\hline $\begin{array}{l}\text { 3. Take part in marketing social } \\
\text { practices }\end{array}$ & 0.083 & 0.067 & -0.008 & 0.118 & -0.133 & 0.004 & 0.021 & 0.645 & 0.003 \\
\hline $\begin{array}{l}\text { 4. Allocate the human, material or } \\
\text { financial resources of an } \\
\text { organisation }\end{array}$ & 0.015 & 0.004 & 0.057 & 0.013 & -0.063 & 0.043 & 0.035 & 0.797 & -0.010 \\
\hline $\begin{array}{l}\text { 5. Meet important executives or } \\
\text { leaders }\end{array}$ & -0.091 & -0.018 & -0.012 & 0.158 & -0.003 & -0.013 & 0.069 & 0.697 & 0.016 \\
\hline $\begin{array}{l}\text { 6. Pay attention to the sales of } \\
\text { listed companies }\end{array}$ & -0.067 & 0.075 & 0.060 & 0.051 & 0.029 & 0.017 & 0.033 & 0.627 & 0.087 \\
\hline \multicolumn{10}{|l|}{ Factor 9: Adventurous } \\
\hline $\begin{array}{l}\text { 1. Play extreme sports such as roller } \\
\text { skating or bike stunts }\end{array}$ & 0.055 & -0.033 & 0.015 & 0.119 & -0.071 & 0.054 & -0.042 & 0.004 & 0.665 \\
\hline 2. Explore uninhabited areas & 0.011 & 0.146 & -0.112 & -0.084 & 0.016 & 0.027 & 0.016 & 0.033 & 0.776 \\
\hline 3. Climb a perilous peak & 0.014 & -0.022 & -0.055 & -0.015 & -0.017 & 0.046 & 0.058 & 0.038 & 0.826 \\
\hline $\begin{array}{l}\text { 4. Engage in dangerous rescue work } \\
\text { like fire-fighting }\end{array}$ & -0.072 & 0.034 & 0.070 & 0.028 & 0.002 & 0.111 & 0.106 & -0.046 & 0.670 \\
\hline 5. Become a professional race driver & 0.017 & -0.003 & 0.014 & 0.194 & 0.038 & 0.004 & -0.113 & 0.047 & 0.647 \\
\hline $\begin{array}{l}\text { 6. Undertake criminal investigation } \\
\text { work }\end{array}$ & -0.036 & 0.026 & 0.008 & 0.019 & 0.085 & -0.025 & 0.074 & -0.022 & 0.558 \\
\hline
\end{tabular}

Note: Factor loadings greater than .30 in boldface type. These items were in Chinese when used in testing.

of translation, the scale was translated into Chinese, then blind back-translated into English, and translated into Chinese again by two researchers proficient in Chinese and English. The internal consistency of subscales ranges from .72 to .92 , and the test-retest stability correlations ranges from .76 to .89 (Holland, Powell, \& Fritzsche, 1997)

\section{Statistical Analysis}

The rate of missing data in this study was below $0.5 \%$. All of the absolute values of skewness of the 54 variables were under 1.0, and 51 variables had an absolute value of kur- tosis under 1.0 (the remaining three values were no larger than 1.5). Based on the same considerations as in study 1 , the CFA was conducted by Mplus 7.11 with WLSMV and the default mode of handling missing data (Muthén \& Muthén, 1998-2012). Correlations among factors were freely estimated. The chi-square, RMSEA, CFI, and TLI were adopted as the four indexes to evaluate model fitness. The internal consistency reliability, test-retest reliability, and convergent validity were also examined with SPSS 18.0 using the 'listwise' method for removing missing data. 
Table 4

The Internal Consistency Reliability, Means, Standard Deviations and Correlation Matrix of the Nine Subscales for the EFA Sample $(n=989)$

\begin{tabular}{|c|c|c|c|c|c|c|c|c|c|c|c|c|}
\hline & Cronbach's $\alpha$ & $M$ & $S D$ & 1 & 2 & 3 & 4 & 5 & 6 & 7 & 8 & 9 \\
\hline 1. Artistic & .76 & 3.80 & .83 & 1.00 & $.16^{*}$ & $.18^{*}$ & $.31 *$ & $.12^{*}$ & $.16^{*}$ & $.23^{*}$ & $.21 *$ & $.16^{*}$ \\
\hline 2. Biotic & .87 & 3.62 & 1.02 & & 1.00 & $.27^{*}$ & $.09 *$ & $.31^{*}$ & $.24^{*}$ & $.17^{*}$ & .06 & $.27^{*}$ \\
\hline 3. Conventional & .80 & 3.83 & .87 & & & 1.00 & $.19 *$ & $.26^{*}$ & $.25^{*}$ & $.36^{*}$ & $.30 *$ & .04 \\
\hline 4. Expressive & .85 & 3.55 & 1.01 & & & & 1.00 & .04 & .03 & $.26^{*}$ & $.40 *$ & $.19^{*}$ \\
\hline 5. Investigative & .85 & 4.12 & .86 & & & & & 1.00 & $.36 *$ & $.23^{*}$ & $.37^{*}$ & $.20 *$ \\
\hline 6. Operational & .86 & 3.66 & .98 & & & & & & 1.00 & $.11^{*}$ & $.26^{*}$ & $.30 *$ \\
\hline 7. Social & .87 & 4.59 & .77 & & & & & & & 1.00 & $.38 *$ & $.13^{*}$ \\
\hline 8. Enterprising & .87 & 4.22 & .89 & & & & & & & & 1.00 & $.16^{*}$ \\
\hline 9. Adventurous & .84 & 3.53 & 1.07 & & & & & & & & & 1.00 \\
\hline
\end{tabular}

Note: Subscales' correlations were reported.

$* p<.05$

Table 5

CFA Model Fit Statistics for the Nine-Factor Chinese Vocational Interest Model $(n=970)$

\begin{tabular}{llllll}
\hline$\chi^{2}$ & $d f$ & RMSEA & RMSEA [90\% Cl] & CFI & TLI \\
\hline $3869.237^{* *}$ & 1341 & 0.044 & {$[0.042,0.046]$} & 0.935 & 0.931
\end{tabular}

Note: RMSEA = root mean square error of approximation; $\mathrm{Cl}$ = confidence interval; $\mathrm{CFI}=$ comparative fit index; TLI = Tucker-Lewis index.

$* * p<.01$

\section{Results}

\section{Confirmatory Factor Analysis}

The nine-factor model of the vocational interest scale was tested, and Table 5 showed that the model fit well to the data. RMSEA was below the accepted .05 cutoff for good fit (McDonald \& Ho, 2002). CFI and TLI was above the accepted .90 cutoff (Hu \& Bentler, 1999). All the items loaded significantly on the corresponding factor. Only two factor loadings fell below .60 (.52 and .51 respectively). Over half of the factor loadings were above .70 in this sample (see Table 6). As above, the results of the CFA provided us with good construct validity evidence for the Chinese Vocational Interests Scale.

\section{Reliability}

Internal consistency reliabilities of the subscales and testretest correlations were found to be adequate (see Table 7).

\section{Concurrent Validity}

To assess the concurrent validity of the Chinese Vocational Interests Scale, we computed the correlations between the subscales of our Vocational Interests Scale with subscales of the SDS (Table 8$)$. Due to the sample size $(n=970)$, most correlations were significant. If the new scale has high construct validity, similar dimensions in the new scale and types in SDS would show as least moderate correlations. Result found that the correlations of six pairs, including Realistic (equals Operational in the Chinese Vocational Interests Scale), Investigative, Artistic, Social, Enterprising, and Conventional did present moderate cor- relations, which were higher than others (see Table 9), as expected.

\section{Discussion}

In study 2, we confirmed the construct validity of the Vocational Interests Scale. The results of a CFA revealed that the 9-factor model fit the data well. Then, we computed the internal consistency reliabilities of the scale and found all the subscales were reliable enough, with most of the Cronbach's alphas above .70. Evidence from convergent validity supported the construct of the Chinese Vocational Interests Scale. Specifically, similar types and dimensions (Realistic, Investigative, Artistic, Social, Enterprising, and Conventional) between the Holland's model and the new developed scale showed the highest correlations.

\section{General Discussion}

We used an emic approach to develop an item pool of 96 indigenous vocational interests, then explored and validated the structure of these items with a factor analytic approach. In the item generation phase, we used an openended survey to produce new items and also referred to an existing instrument in order to obtain a comprehensive representation of Chinese vocational interests. The EFA results yielded nine meaningful factors, and the CFA results proved good fit of the nine-factor model to another sample in China. All the internal consistency reliabilities and most of the test-retest correlations of the subscales were above 0.70 . The correlations of resembling subscales between the new scale and the SDS were relatively higher, providing convergent validity. In conclusion, the present study brought an expansion to the view of vocational interest research with an emic approach from a crosscultural perspective, and the Chinese Vocational Interests Scale was found to have good psychometric properties and therefore could be used as an applicable and relatively short measure of vocational interests for Chinese populations.

The results of the present study indicated that there were nine latent dimensions of young Chinese people's vocational interests: Artistic (A), Biotic (B), Conventional 
Table 6

Standardised CFA Factor Loadings for the Nine-Factor Chinese Vocational Interest Model $(n=970)$

\begin{tabular}{|c|c|c|c|c|c|c|c|c|c|}
\hline Artistic & Loadings & Biotic & Loadings & Conventional & Loadings & Expressive & Loadings & Investigative & Loadings \\
\hline Item 2 & $.67(.02)$ & Item 2 & $.84(.01)$ & Item 2 & $.72(.02)$ & Item 2 & $.73(.02)$ & Item 2 & $.79(.02)$ \\
\hline Item 4 & $.51(.03)$ & Item 4 & $.81(.01)$ & Item 4 & $.62(.03)$ & Item 4 & $.63(.02)$ & Item 4 & $.75(.02)$ \\
\hline Item 5 & $.77(.02)$ & Item 5 & $.74(.02)$ & Item 5 & $.71(.02)$ & Item 5 & $.79(.02)$ & Item 5 & $.77(.02)$ \\
\hline Item 6 & $.80(.02)$ & Item 6 & $.77(.02)$ & Item 6 & $.66(.02)$ & Item 6 & $.70(.02)$ & Item 6 & $.74(.02)$ \\
\hline Item 1 & $.61(.02)$ & Item 1 & $.80(.02)$ & Item 1 & $.82(.01)$ & Item 1 & $.63(.02)$ & & \\
\hline Item 2 & $.75(.02)$ & Item 2 & $.72(.02)$ & Item 2 & $.79(.01)$ & Item 2 & $.80(.02)$ & & \\
\hline Item 3 & $.69(.02)$ & Item 3 & $.80(.01)$ & Item 3 & $.71(.02)$ & Item 3 & $.85(.01)$ & & \\
\hline Item 4 & $.84(.01)$ & Item 4 & $.75(.02)$ & Item 4 & $.78(.02)$ & Item 4 & $.79(.02)$ & & \\
\hline Item 5 & $.83(.01)$ & Item 5 & $.73(.02)$ & Item 5 & $.76(.02)$ & Item 5 & $.64(.02)$ & & \\
\hline
\end{tabular}

Note: Values in parentheses are standard errors of factor loadings.

\section{Table 7}

Reliability, Means, Standard Deviations and Correlation Matrix of the Nine Subscales

\begin{tabular}{|c|c|c|c|c|c|c|c|c|c|c|c|c|c|}
\hline & Cronbach's $\alpha$ & Test-retest & M & $S D$ & 1 & 2 & 3 & 4 & 5 & 6 & 7 & 8 & 9 \\
\hline 1. Artistic & .77 & .73 & 3.84 & .85 & 1.00 & $.20 * *$ & $.25^{* *}$ & $.42 * *$ & $.16^{* *}$ & $.09 * *$ & $.27^{* *}$ & $.25^{* *}$ & $.13^{* *}$ \\
\hline 2. Biotic & .88 & .74 & 3.65 & 1.03 & & 1.00 & $.21^{* *}$ & $.10^{* *}$ & $.37^{* *}$ & $.28^{* *}$ & $.14^{* *}$ & $.09^{* *}$ & $.34^{* *}$ \\
\hline 3. Conventional & .80 & .73 & 3.82 & .86 & & & 1.00 & $.16^{* *}$ & $.34^{* *}$ & $.23^{* *}$ & $.33^{* *}$ & $.31 * *$ & .02 \\
\hline 4. Expressive & .83 & .78 & 3.57 & .95 & & & & 1.00 & $.09 * *$ & .01 & $.29 * *$ & $.36 * *$ & $.19^{* *}$ \\
\hline 5. Investigative & .85 & .71 & 4.07 & .87 & & & & & 1.00 & $.43^{* *}$ & $.26^{* *}$ & $.37^{* *}$ & $.22^{* *}$ \\
\hline 6. Operational & .87 & .77 & 3.66 & .98 & & & & & & 1.00 & $.07^{*}$ & $.23^{* *}$ & $.34^{* *}$ \\
\hline 7. Social & .87 & .63 & 4.55 & .77 & & & & & & & 1.00 & $.37^{* *}$ & $.07^{*}$ \\
\hline 8. Enterprising & .87 & .71 & 4.22 & .86 & & & & & & & & 1.00 & $.10^{* *}$ \\
\hline 9. Adventurous & .83 & .70 & 3.59 & 1.06 & & & & & & & & & 1.00 \\
\hline
\end{tabular}

Note: Subscales' correlations were reported.

** $p<.01 ; * p<.05$.

\section{Table 8}

Means, Standard Deviations and Correlation Matrix of Self-Directed Search (SDS)

\begin{tabular}{lllllllll}
\hline & $M$ & $S D$ & 1 & 2 & 3 & 4 & 5 & \multicolumn{1}{l}{6} \\
\hline 1. H_Realistic & 5.43 & 3.42 & 1.00 & $.47^{* *}$ & $-.12^{* *}$ & .02 & $.09^{* *}$ & $.26^{* *}$ \\
2. H_Investigative & 5.36 & 3.09 & & 1.00 & $-.09^{* *}$ & $.19^{* *}$ & $.10^{* *}$ & $.32^{* *}$ \\
3. H_Artistic & 6.83 & 3.05 & & & 1.00 & $.32^{* *}$ & $.22^{* *}$ & $.12^{* *}$ \\
4. H_Social & 7.24 & 2.27 & & & & 1.00 & $.33^{* *}$ & $.32^{* *}$ \\
5. H_Enterprising & 8.07 & 2.85 & & & & & 1.00 & $.34^{* *}$ \\
6. H_Conventional & 5.62 & 3.05 & & & & & & 1.00
\end{tabular}

Note: Subscales' correlations were reported. H_Realistic, H_Investigative, H_Artistic, H_Social, H_Enterprising,

$\mathrm{H} \_$Conventional are the six dimensions in the Self-Directed Search (SDS).

$* * p<.01 ; * p<.05$.

\section{Table 9}

Correlations of the Subscales Between the Chinese Vocational Interests Scale and the Self-Directed Search

\begin{tabular}{llllllllll}
\hline & Artistic & Biotic & Conventional & Expressive & Investigative & Operational & Social & Enterprising & Adventurous \\
\hline H_Realistic & .05 & $.22^{* *}$ & $.11^{* *}$ & $-.09^{* *}$ & $.32^{* *}$ & $.64^{* *}$ & -.04 & $.16^{* *}$ & $.35^{* *}$ \\
H_Investigative & .03 & $.27^{* *}$ & $.19^{* *}$ & -.03 & $.48^{* *}$ & $.42^{* *}$ & $.07^{*}$ & $.19^{* *}$ & $.20^{* *}$ \\
H_Artistic & $.53^{* *}$ & $.09^{* *}$ & $.13^{* *}$ & $.43^{* *}$ & .00 & $-.11^{* *}$ & $.25^{* *}$ & $.14^{* *}$ & .06 \\
H_Social & $.23^{* *}$ & $.17^{* *}$ & $.28^{* *}$ & $.17^{* *}$ & $.24^{* *}$ & .03 & $.49^{* *}$ & $.22^{* *}$ & .06 \\
H_Enterprising & $.18^{* *}$ & -.01 & $.20^{* *}$ & $.29^{* *}$ & $.19^{* *}$ & .06 & $.27^{* *}$ & $.58^{* *}$ & -.01 \\
H_Conventional & $.14^{* *}$ & $.10^{* *}$ & $.55^{* *}$ & .05 & $.28^{* *}$ & $.26^{* *}$ & $.22^{* *}$ & $.32^{* *}$ & .00 \\
\hline
\end{tabular}

Note: H_Realistic, H_Investigative, H_Artistic, H_Social, H_Enterprising, H_Conventional are the six dimensions in the SDS.

${ }^{* *} p<.01 ; * p<.05$. 
(C), Expressive (X), Investigative (I), Operational (O), Social (S), Enterprising (E), and Adventurous (V). The six RIASEC interest types from Holland's model were included in the new model; for example, the dimension 'Operational' $(\mathrm{O})$ in the nine-factor model is quite similar to the type 'Realistic' (R) in the Holland's model, both referring to a preference for practical works requiring operating tools and using machines. However, the nine-factor model in the present study is totally different from the Holland's RIASEC model in methodology, and consequently, the meaning of those vocational interests of two models are not the same even though they have similar descriptions. In the present study, researchers assumed that occupation preference reflected personal traits, so we could extract latent attributes behind different vocational activities; for example, the factor called 'Social', which reflects interest in social services and prosocial behaviors, and those who obtain a high score in this factor are usually outgoing and helpful.

There were three dimensions - Expressive (X), Adventurous (V), and Biotic (B) - simultaneously presented in the Chinese sample compared to Holland's RIASEC model. The appearance of each of the three dimensions is buttressed by indirect evidence from the literature.

The presence of the dimension 'Expressive' complies with the dimensions of the Jackson Vocational Interest Survey (JVIS; Jackson, 1977, 2000), whose reliability and validity has been confirmed by Schermer and MacDougall (2011). A distinct dimension of 'Performing Arts' (similar to 'Expressive' here) should be separated from 'Artistic' to describe those who enjoy performing in front of an audience. We believe that there are social reasons for the emergence of the 'Expressive' dimension. The prosperity of the entertainment industry and the prevalence of Fan Culture have had a significant impact on teenagers and young adults, making them long for the opportunity to present themselves and become the focus of attention. When becoming an idol becomes an actual profession, it is better to recognise the dimension of 'Expressive' to help us understand those who prefer to perform in public and influence others through their performance and personal charm.

As for the dimension 'Adventurous', this is included in the Oregon Vocational Interest Scales (Pozzebon, Visser, Ashton, Lee, \& Goldberg, 2010) as one of eight major dimensions, and is also included in the Campbell Interest and Skills Survey as one of its seven orientations. This dimension reflects a different and important aspect of 'Realistic' in Holland's RIASEC model, which involves activities requiring risk taking, physical endurance, and excitement seeking. In fact, society is always in need of risk-taking occupations such as firemen and aviators. Besides, many extreme sports have become popular in China. Therefore, we cannot ignore this dimension of 'Adventurous' that focuses on people's orientation toward pursuing excitement and challenges.

In terms of the dimension 'Biotic', a previous study derived from Chinese samples suggested a similar type,
'Natural', to add to Chinese vocational interests (H. Zhang et al., 2004). The eight-type model from the Personal Globe Inventory also includes the 'Nature/Outdoors' basic type (Y. Zhang et al., 2013). The presence of this dimension may be a result of the demand for environmental protection. The Chinese government has taken the issue of ecological conservation more seriously because of rapid urbanisation and industrial development, not to mention that it is already a global issue. This country, and even the world, is calling for more professionals in eco-industries such as eco-breeding or forestry, and some new professionals, such as environmental engineers, have emerged. Leadership from government will transfer more public attention to nature to facilitate bioticrelated job availability. This job availability may further encourage young students to freely develop their passion for the natural environment. Thus, the Biotic dimension will have its place in Chinese general vocational interest categories.

Cross-cultural research on vocational interests using cluster and factor analytic approaches has shown divergence from the RIASEC types. It is judicious to always keep the measurement of vocational interests veracious and in accordance with our times and our societies. Liu and Rounds (2003) examined the fitness of five of Holland's RIASEC related models in China, but did not find adequate support for the six vocational interest types. Einarsdóttir, Eyjólfsdóttir, and Rounds (2013) identified eight broad interest categories in Iceland that differ from RIASEC types and partly converge with the Chinese categories in the present study. Primavera et al. (2010) identified nine broad interest categories in the Philippines, which is quite different from the Chinese categories. And factor analytic research in the United States also did not find the common interest factors in different populations with a similar culture (Liao, Armstrong, \& Rounds, 2008; Rounds, 1995).

This exploratory research also has its limitations. First, although the SDS had been criticised for its unfitness in Chinese culture, we nevertheless had to choose it as an indicator of construct validity. This was because that we could not find a suitable vocational interest scale in China or a better scale than the SDS, which is well constructed and has been validated in the United States and other countries. As a result, the validity of the nine-factor model needs to be verified with more evidence, especially regarding criterion-related validity. We recommend various criteria be used at the same time (e.g., job satisfaction, job selection, and achievement in career). Second, the psychometric invariance of the present model is waiting to be tested under diverse populations, rather than be limited to the college students group as in the present study. Third, although this study has initially proved the existence of the nine-factor model of Chinese vocational interests, its spatial structure still remains unknown. Future studies could keep exploring the vocational interests in China and uncover its spatial structure. 


\section{Appendix}

\section{Table 10}

54 items in the Chinese Vocational Interests Scale (English version)

\section{Factor 1: Artistic}

1. Design packaging of a new product

2. Design the logo of a company or an organization

3. Create portraits or photographs

4. Write lyrics or compose music of any kind

5. Design furniture, clothing, or posters

6 . Design stage scenery for a play

Factor 2: Biotic

1. Watch documentary films or TV programs about animals or other creatures

2. Observe or record the growth of plants

3. Collect or make biological specimens

4. Track or observe wild animals

5. Cultivate new varieties of animals or plants

6. Observe or record the habits of small animals like ants

Factor 3: Conventional

1. Regularly make neat or update an address book

2. Take inventory of supplies or products

3. Check paperwork or products for errors or flaws

4. Keep detailed records of expenses

5. Handle daily affairs in office

6. Classify or put different kinds of items in order

Factor 4: Expressive

1. Perform dance or traditional Chinese Opera for others

2. Become a public figure

3. Be the emcee or compere of a show or a TV program

4. Dress myself out of the ordinary

5. Become the image endorsement of a product or company

6 . Attend an event as an award presenter

Factor 5: Investigative

1. Explore the causes of a phenomenon or an incident

2. Verify a scientific theory with practice

3. Think about the principles of how things develop or change

4. Learn about different scientific theories via books or lectures

5. Study a certain theory in depth through a series of references or data.

6 . Apply science to practical problems

Factor 6: Operational

1. Maintain a computer network

2. Shape metal or plastic with tools

3. Repair garments or electronic equipment

4. Operate machines or devices

5. Assemble precision instruments or meters

6. Refit computers or other equipment in order to improve their efficiency

Factor 7: Social

1. Talk with people to help make them happy

2. Help tutoring neighborhood children

3. Care about poor, sick or lonely people

4. Work for a charity

5. Keep neighboring elderly people company

6. Encourage colleagues when they are feeling down or faced with difficulties

Factor 8: Enterprising

1. Plan for the developmental orientation of a team or company

2. Make investment analysis for a company

3. Take part in marketing social practices

4. Allocate the human, material or financial resources of an organization

5. Meet important executives or leaders

6. Pay attention to the sales of listed companies

Factor 9: Adventurous

1. Play extreme sports such as roller skating or bike stunts

2. Explore uninhabited areas

3. Climb a perilous peak

4. Engage in dangerous rescue work like fire-fighting

5. Become a professional race driver

6. Undertake criminal investigation work

\section{Table 11}

54 items in the Chinese Vocational Interests Scale (Chinese version)

因子1:艺术型

1. 设计公司新产品的包装。

2.设计公司或组织的标志。

3.画人物肖像或摄影。

4.作词或作曲。

5.设计家具、服饰或海报。

6. 设计舞台布景。

因子2:生态型

1.看动物世界或其它生物纪录片。

2.观察记录植物的生长习性。

3.收集或制作生物标本。

4.跟踪、观察或记录野生动物的生活习性。

5.培育动物或植物新品种。

6 . 观察蚂蚁或其它的动物的生活习性。

因子3:常规型

1.定期整理通讯录。

2.盘点各种物资或产品。

3. 审查文件或文字材料中的错误。

4.保留各种开销的详单。

5.处理办公室日常事务。

6 . 将不同物品分类摆放整齐。

因子4:表现型

1.表演舞蹈或戏曲。

2. 成为公众人物。

3. 主持节目。

4.把自己打扮得与众不同。

5.做公司或产品的形象代言。

6.作为颁奖嘉宾出席活动。

因子5:研究型

1.探索某种现象或事件产生的原因。

2.用实践验证某种科学理论。

3.思考事物发展变化的规律。

4. 从书籍或讲座中了解不同科学家的理论。

5.从一系列资料中深人地了解某一理论。

6. 应用科学知识来解决实际问题。

因子6:操作型

1.电脑网络维护。

2.利用机械工具加工金属或塑料。

3. 修补服装饰品或修理电子设备。

4.操作仪器或设备。

5.装配精密的仪器仪表。

6.改装电脑或其它用具，以提高功效。

因子7:社会型

1.开导他人以解开心结。

2. 帮邻居的孩子辅导功课。

3.关心贫困有病或孤独寂寞的人。

4. 为慈善组织工作。

5.陪伴照顾邻里的老人。

6. 在同事情绪低落或遭遇挫折时鼓励他人。

因子8:企业型

1.规划一个团队或公司的发展方向。

2. 为公司作投资分析。

3.参加营销类的社会实践。

4. 合理调配公司或组织的人力、物力和财力。

5.结识公司高管或企业领导。

6.关注上市公司业绩。

因子9:冒险型

1.玩旱冰或车技等极限运动。

2.去荒无人烟的地区探险。

3.攀登险峰。

4. 从事存在危险的救援工作, 如消防员。

5.做职业赛车手。

6. 从事刑侦工作。 


\section{References}

Ægisdóttir, S., Gerstein, L.H., Leung, S.M.A., Kwan, K.L.K., \& Lonner, W.J. (2009). Theoretical and methodological issues when studying culture. In L.H. Gerstein, P.P. Heppner, S. Ægisdóttir, S.M.A. Leung, \& K.L. Norsworthy (Eds.), International handbook of cross-cultural counseling: Cultural assumptions and practices worldwide (pp. 89-109). Thousand Oaks, CA: Sage.

Baron, H. (1996). Strengths and limitations of ipsative measurement. Journal of Occupational and Organizational Psychology, 69, 49-56. doi:10.1111/j.2044-8325.1996.tb00599.x

Borgen, F.H., \& Lindley, L.D. (2003). Individuality and optimal human functioning: Interests, self-efficacy, and personality. In W.B. Walsh (Ed.), Counseling psychology and optimal human functioning (pp. 55-91). Hillsdale, NJ: Lawrence Erlbaum.

Campbell, D.P., \& Borgen, F.H. (1999). Holland's theory and the development of interest inventories. Journal of Vocational Behavior, 55, 86-101. doi:10.1006/jvbe.1999.1699

Campbell, D.P., Hyne, S.A., \& Nilsen, D.L. (1992). Manual for the Campbell Interest and Skills Inventory. Minneapolis, MN: National Computer Systems.

Carless, S.A. (1999). Career assessment: Holland's vocational interests, personality characteristics, and abilities. Journal of Career Assessment, 7, 125-144. doi:10.1177/106907279900700203

Cattell, R.B. (1966). The screen test for the number of factors. Multivariate Behavioral Research, 1, 245-276. doi:10.1207/s15327906mbr0102_10

Cheung, F.M., Leung, K., Fan, R.M., Song, W.Z., Zhang, J.X., \& Zhang, J.P. (1996). Development of the Chinese personality assessment inventory. Journal of Cross-Cultural Psychology, 27, 181-199. doi:10.1177/0022022196272003

Cheung, F.M., Leung, K., Zhang, J.X., Sun, H.F., Gan, Y.Q., Song, W.Z., \& Xie, D. (2001). Indigenous Chinese personality constructs - Is the five-factor model complete? Journal of Cross-Cultural Psychology, 32, 407-433. doi: 10.1177/0022022101032004003

Cheung, G.W., \& Rensvold, R.B. (2002). Evaluating goodness-of-fit indexes for testing measurement invariance. Structural Equation Modeling, 9, 233-255. doi: 10.1207/s15328007sem0902_5

Church, A.T. (1987). Personality-research in a nonwestern culture - the Philippines. Psychological Bulletin, 102, 272-292. doi:10.1037//0033-2909.102.2.272

Day, S.X., \& Rounds, J. (1997). 'A little more than kin, and less than kind': Basic interests in vocational research and career counseling. Career Development Quarterly, 45, 207220.

Deng, C.-P., Armstrong, P.I., \& Rounds, J. (2007). The fit of Holland's RIASEC model to US occupations. Journal of Vocational Behavior, 71, 1-22. doi:10.1016/j.jvb.2007.04.002

Dik, B.J., \& Hansen, J.-I.C. (2008). Following passionate interests to well-being. Journal of Career Assessment, 16, 86-100. doi:10.1177/1069072707305773

Donnay, D.A.C., Morris, M.A., Shaubhut, N.A., \& Thompson, R.C. (2005). Strong Interest Inventory manual: Research, development, and strategies for interpretation. Palo Alto, CA: Consulting Psychologists Press.

Einarsdóttir, S., Eyjólfsdóttir, K.Ó., \& Rounds, J. (2013). Development of indigenous basic interest scales: re-structuring the icelandic interest space. Journal of Vocational Behavior, 82(2), 105-115.

Einarsdóttir, S., Eyjólfsdóttir, K.Ó., \& Rounds, J. (2013). Development of indigenous basic interest scales: Re-structuring the Icelandic interest space. Journal of Vocational Behavior, 82, 105-115. doi:10.1016/j.jvb.2013.01.001

Einarsdóttir, S., Rounds, J., \& Su, R. (2010). Holland in Iceland revisited: An emic approach to evaluating US vocational interest models. Journal of Counseling Psychology, 57, 361. doi:10.1037/a0019685

Fabrigar, L.R., Wegener, D.T., MacCallum, R.C., \& Strahan, E.J. (1999). Evaluating the use of exploratory factor analysis in psychological research. Psychological Methods, 4, 272-299. doi:10.1037//1082-989x.4.3.272

Farth, J., Leong, F.T.L., \& Law, K.S. (1998). Cross-cultural validity of Holland's model in Hong Kong. Journal of Vocational Behavior, 52, 425-440. doi:10.1006/jvbe.1997.1631

Finney, S.J., \& DiStefano, C. (2013). Nonnormal and categorical data in structural equation modeling. In G.R. Hancock \& R.O. Mueller (Eds.), Structural equation modeling: A second course (2nd ed., pp. 439-492). Charlotte, NC: Information Age Publishing

Hansen, J.C. (2005). Assessment of interests. In S.D. Brown \& R.W. Lent (Eds.), Career development and counseling: Putting theory and research to work (2nd ed., pp. 281-304). Hoboken, NJ: John Wiley

Harmon, L.W., Hansen, J.I.C., Borgen, F.H., \& Hammer, A.L. (1994). Strong Interest Inventory: Applications and technical guide. Palo Alto, CA: Consulting Psychologists.

Holland, J.L. (1973). Making vocational choices: A theory of careers. Englewood Cliffs, NJ: Prentice-Hall.

Holland, J.L. (1985a). Making vocational choices: A theory of vocational personalities and work environments (2nd ed.). Englewood Cliffs, NJ: Prentice Hall.

Holland, J.L. (1985b). Vocational preference inventory. Lutz, FL: Psychological Assessment Resources.

Holland, J.L. (1994). Self-Directed Search, Form R (4th ed.). Odessa, FL: Psychological Assessment Resources.

Holland, J.L. (1997). Making vocational choices: A theory of vocational personalities and work environments ( $3 \mathrm{rd}$ ed.). Odessa, FL: Psychological Assessment Resources.

Holland, J.L., \& Gottfredson, G.D. (1992). Studies of the hexagonal model - An evaluation (or, the perils of stalking the perfect hexagon). Journal of Vocational Behavior, 40, 158170. doi:10.1016/0001-8791(92)90063-6

Holland, J.L., \& Messer, M.A. (2013). Self-Directed Search (SDS) (5th ed.). Lutz, FL: Psychological Assessment Resources.

Holland, J.L., Powell, A.B., \& Fritzsche, B.A. (1997). Self-Directed Search professional user's guide. Odessa, FL: Psychological Assessment Resources.

Hu, L.-T., \& Bentler, P.M. (1999). Cutoff criteria for fit indexes in covariance structure analysis: Conventional criteria versus 
new alternatives. Structural Equation Modeling-a Multidisciplinary Journal, 6, 1-55. doi:10.1080/10705519909540118

Humphreys, L.G., \& Yao, G. (2002). Prediction of graduate major from cognitive and self-report test scores obtained during the high school years. Psychological Reports, 90, 3-30. doi: $10.2466 /$ pr0.90.1.3-30

Jackson, D.N. (1977). Jackson vocational interest survey manual. Port Huron, MI: Research Psychologists Press.

Jackson, D.N. (2000). Jackson vocational interest survey manual (2nd ed.). Port Huron, MI: Research Psychologists Press.

Larson, L.M., Bonitz, V.S., \& Pesch, K.M. (2013). Assessing key vocational constructs. In W.B. Walsh, M.L. Savickas \& P.J. Hartung (Eds.), Handbook of vocational psycholoy: Theory, research and practice (4th ed., pp. 219-248). New York, NY: Routledge.

Liao, H.Y., Armstrong, P.I., \& Rounds, J. (2008). Development and initial validation of public domain Basic Interest Markers. Journal of Vocational Behavior, 73, 159-183. doi:10.1016/j.jvb.2007.12.002

Liu, C., \& Rounds, J. (2003). Evaluating the structure of vocational interest in China. Acta Psychological Sinica, 35, 411418.

Long, L.R., Adams, R.S., \& Tracey, T.J.G. (2005). Generalizability of interest structure to China: Application of the personal globe inventory. Journal of Vocational Behavior, 66, 66-80. doi:10.1016/j.jvb.2003.12.004

Long, L.R., \& Tracey, T.J.G. (2006). Structure of RIASEC scores in China: A structural meta-analysis. Journal of Vocational Behavior, 68, 39-51. doi: 10.1016/j.jvb.2005.01.002

Low, K.D., Yoon, M., Roberts, B.W., \& Rounds, J. (2005). The stability of vocational interests from early adolescence to middle adulthood: A quantitative review of longitudinal studies. Psychological Bulletin, 131, 713. doi:10.1037/0033-2909.131.5.713

McDonald, R.P., \& Ho, M.H.R. (2002). Principles and practice in reporting structural equation analyses. Psychological Methods, 7, 64-82. doi:10.1037//1082-989x.7.1.64

Meade, A.W., Johnson, E.C., \& Braddy, P.W. (2008). Power and sensitivity of alternative fit indices in tests of measurement invariance. Journal of Applied Psychology, 93, 568-592. doi:10.1037/0021-9010.93.3.568

Ministry of Education of the P.R. China. (2012, September 18). Directory of undergraduate majors in China's colleges and universities (2012) [in Chinese]. Retrieved September 21, 2017, from http://www.moe.gov.cn/ srcsite/A08/moe_1034/s3882/201209/t20120918_143152.html

Muthén, L.K., \& Muthén, B.O. (1998-2012). Mplus User's Guide (7th ed.). Los Angeles, CA: Muthén \& Muthén.

Nauta, M.M. (2010). The development, evolution, and status of Holland's theory of vocational personalities: Reflections and future directions for counseling psychology. Journal of Counseling Psychology, 57, 11-22. doi:10.1037/a0018213

Primavera, M.T., Church, A.T., Katigbak, M.S., Bruna, L., White, J.R., \& Peradilla, I. (2010). The structure of vocational interests in Filipino adolescents. Journal of Vocational Behavior, 77, 213-226.
Pozzebon, J.A., Visser, B.A., Ashton, M.C., Lee, K., \& Goldberg, L.R. (2010). Psychometric characteristics of a public-domain self-report measure of vocational interests: The Oregon Vocational Interest Scales. Journal of Personality Assessment, 92, 168-174. doi:10.1080/00223890903510431

Rayman, J., \& Atanasoff, L. (1999). Holland's theory and career intervention: The power of the hexagon. Journal of Vocational Behavior, 55, 114-126. doi:10.1006/jvbe.1999.1701

Rottinghaus, P.J., \& Dik, B.J. (2013). Assessment of Interests. In K.F. Geisinger (Ed.), APA handbook of testing and assessment in psychology: Vol. 2. Testing and assessment in clinical and counseling psychology (vol. 2, pp. 325-348). Washington, DC: American Psychological Association.

Rottinghaus, P.J., Hees, C.K., \& Conrath, J.A. (2009). Enhancing job satisfaction perspectives: Combining Holland themes and basic interests. Journal of Vocational Behavior, 75, 139151. doi:10.1016/j.jvb.2009.05.010

Rounds, J. (1995). Vocational interests: Evaluating structural hypotheses. In D.J. Lubinski \& R.V. Dawis (Eds.), Assessing individual differences in human behavior: New concepts, methods, and findings (pp. 177-232). Palo Alto, CA: Davies-Black Publishing.

Savickas, M.L., Taber, B.J., \& Spokane, A.R. (2002). Convergent and discriminant validity of five interest inventories. Journal of Vocational Behavior, 61, 139-184. doi:10.1006/jvbe.2002.1878

Schermer, J.A. (2012). The Jackson Career Explorer: Two further validity studies. Journal of Career Assessment, 20, 507-519. doi:10.1177/1069072712450288

Schermer, J.A., \& MacDougall, R. (2011). The Jackson Career Explorer in relation to the Career Directions Inventory. Journal of Career Assessment, 19, 442-451. doi:10.1177/1069072711409721

Spokane, A.R. (1985). A review of research on person - Environment congruence in Holland's-theory of careers. Journal of Vocational Behavior, 26, 306-343. doi:10.1016/0001-8791(85)90009-0

Tang, M. (2001). Investigation of the structure of vocational interests of Chinese college students. Journal of Career Assessment, 9, 365-379.

Tang, M. (2009). Examining the application of Holland's theory to vocational interests and choices of Chinese college students. Journal of Career Assessment, 17, 86-98. doi:10.1177/1069072708325743

Tracey, T.J.G., \& Rounds, J. (1995). The arbitrary nature of Holland's RIASEC types - A concentric-circles structure. Journal of Counseling Psychology, 42, 431-439. doi:10.1037//0022-0167.42.4.431

Tracey, T.J.G., \& Rounds, J. (1996a). Contributions of the spherical representation of vocational interests Rejoinder. Journal of Vocational Behavior, 48, 85-95. doi:10.1006/jvbe.1996.0009

Tracey, T.J.G., \& Rounds, J. (1996b). The spherical representation of vocational interests. Journal of Vocational Behavior, 48, 3 41. doi:10.1006/jvbe.1996.0002

Tracey, T.J.G., \& Sodano, S.M. (2013). Structure of interests and competence perceptions. In W.B. Walsh, M.L. Savickas, \& 
P.J. Hartung (Eds.), Handbook of vocational psychology: Theory, research, and practice (4th ed., pp. 155-181). New York, NY: Routledge.

Van Iddekinge, C.H., Putka, D.J., \& Campbell, J.P. (2011). Reconsidering vocational interests for personnel selection: The validity of an interest-based selection test in relation to job knowledge, job performance, and continuance intentions. Journal of Applied Psychology, 96, 13-33. doi:10.1037/a0021193

Worthington, R.L., \& Whittaker, T.A. (2006). Scale development research - A content analysis and recommendations for best practices. Counseling Psychologist, 34, 806-838. doi:10.1177/001100006288127

Yang, W., Stokes, G.S., \& Hui, C.H. (2005). Cross-cultural validation of Holland's interest structure in Chinese population. Journal of Vocational Behavior, 67, 379-396. doi:10.1016/j.jvb.2004.08.003

Yung, Y.-F., Chan, W., Cheung, F.M.C., Leung, K., Law, J.S., \& Zhang, J.X. (2000). Standardization of the Chinese Personality Assessment Inventory: The prototype standardization method and its rationale. Asian Journal of Social Psychology, 3, 133-152. doi:10.1111/1467-839X.00059

Zhang, H., Feng, B., \& Yuan, K. (2004). Characteristics of vocational interest of Chinese high school students and the development of interest scale for their college entrance and career guidance. Acta Psychological Sinica, 36, 89-95.

Zhang, Y., Kube, E., Wang, Y., \& Tracey, T.J.G. (2013). Vocational interests in China: An evaluation of the Personal Globe Inventory-Short. Journal of Vocational Behavior, 83, 99-105. doi:10.1016/j.jvb.2013.03.009 